\title{
“Selamat Datang Perang Dingin!" \\ Kepentingan Rusia Di Krimea Dan Ukraina Timur \\ Dan Ketegangan Hubungan Dengan Barat
}

\begin{abstract}
Ali Muhammad ${ }^{1}$
Abstrak

Paper ini berupaya memahami memburuknya hubungan antara Rusia dan Barat (Uni Eropa dan Amerika Serikat) terkait dengan dengan Ukraina. Yang akan menjadi fokus pembahasan adalah mengapa Rusia melakukan anekasi semenajung Krimea dan melakukan intervensi di Ukraina Timur. Inti argumennya adalah bahwa, pertama, aksi aneksasi Rusia sebenarnya adalah hal yang bisa dipahami sebagai puncak reaksi terhadap aksi ekspansi masif pengaruh Barat ke Eropa Timur sejak berakhirnya Perang Dingin. Ukraina hanyalah salah satu sisa-sisa dan benteng akhir mitra Rusia di Eropa Timur. Kejatuhan tragis presiden Viktor Janukovych yang pro-Rusia di negara tersebut hanyalah menjadi faktor pemicu bagi tindakan petualangan Rusia. Kedua, sejauh mana efektivitas respons atau reaksi Barat yang berupa sanksi ekonomi dan diplomatik negara-negara Barat atas Rusia belum bisa dipastikan. Bagi Barat, upaya mengendalikan aksi "illegal" Rusia sangat dilematis mengingat Rusia adalah negara great power. Serangkian aksi Rusia sangat mengkawatirkan Barat dan telah memicu ketegangan serius, yakni, "Perang Dingin Baru” yang tak terelakkan
\end{abstract}

Kata-kata Kunci: Rusia, Barat, Ukraina, Krimea, Ukraina Timur, Perang Dingin

\begin{abstract}
This paper attempts to explain the worsening relationship between Russia and the West (European Union and the United States) related to Ukraine issue. The focus of the discussion is to elaborate why Russia carried out an annexation of Crimea peninsula and intervention in the Eastern Ukraine. The main argument of the paper consists of two points; firstly, annexation by Russia is a peak of reactions against massive expansion of the Western to Eastern Europe since the end of Cold War. Ukraine was the last standing partner of Russia in the Eastern Europe. The tragic fall of Victor Janukovych which was pro-Russia in the country was only a trigger to Russia's action. Secondly, the extent of effectivity of response or reaction from the West, for example the economic and diplomatic sanction of Wester countries to Russia is still uncertain. For the West, the attempts to control the "illegal" action of Russia is found to be a dillematic issue considering that Russia is one of the great powers. This worrisome action by Russia has led to a sirious tension, namely "a New Cold War".
\end{abstract}

Keywords: Rusia, West, Ukraine, Crimea, East Ukraine, Cold War

\footnotetext{
${ }^{1}$ Dr Ali Muhammad, MA adalah dosen Ilmu Hubungan Internasional Universitas Muhammadiyah Yogyakarta. Artikel ini merupakan revisi dari gagasan awal (draf) yang pernah dipresentasikan dalam forum seminar Convention on European Studies di Universitas Gadjah Mada. Email: alimuhammad@umy.ac.id
} 


\section{Pendahuluan}

Perspektif liberal hubungan internasional berpandangan optimis bahwa, di era dewasa ini, tindakan aneksasi teritorial oleh suatu negara terhadap negara lain dipandang sebagai perilaku yang sudah ketinggalan zaman. Argumen dasarnya adalah bahwa kondisi dunia saat ini semakin terintegrasi dan saling tergantung baik secara ekonomi, keuangan, perdagangan, dan investasi sehingga negara-negara di dunia semakin saling tergantung. Aneksasi wilayah oleh suatu negara terhadap negara lainseperti ansluss Jerman era NAZI terhadap Austria - menjadi tindakan anakronis dan tidak rasional karena biaya yang ditanggung terlalu mahal. Namun, pandangan optimis tersebut terguncang oleh peristiwa yang mencengangkan bak petir di siang bolong: tindakan anaksasi Krimea oleh Rusia. Dunia seakan kembali ke masa lalu yang didominasi oleh pertaruangn geopolitik maupun perbutan wilayah: back to the past! Sejarah masa lalu aneksasi wilayah oleh suatu negara terhadap negara lain kembali berulang. Bagaimana hal tersebut bisa terjadi? Mengapa Rusia melakukan aksi illegal tersebut dan, bahkan, melanjutkan intervensinya di Ukraina sebelah Timur tersebut? Seperti kata Kanselir Jerman Angela Merkel, apakah Rusia masih hidup di "dunia lain" atau masih berada di "masa silam"? Bagaimana pula reaksi dan dilemma yang dihadai oleh negara-negara Barat? Paper sederhana ini akan mendiskusikan permasalahan tersebut dan berargumen bahwa tindakan Rusia tersebut justru merupakan tindakan yang bisa dipahami sebagai puncak reaksi terhadap ekspansi pengaruh Barat ke Eropa Timur sejak bubarnya Perang Dingin. Ukraina hanyalah salah satu sisa-sisa banteng akhir mitra Rusia di Eropa Timur. Kejatuhan tragis pemeritahan Viktor Janukovych yang pro-Rusia tersebut menjadi faktor pemicu bagi tindakan aneksasi Rusia terhadap semenjung Krimea dan intervensi militernya di Ukraina Timur. Sejauh mana efektifitas sanksi ekonomi dan diplomatic negara-negara Barat atas Rusia belum bisa dipastikan, namun Barat semakin menghadapi dilema karena harus melakukan respon terhadap tindakan sebuah negara Great power yang semakin nekat melakukan intervensi di wilayah Ukraina Timur dengan mendukung pihak pemberontak pro-Rusia.

\section{Konteks: Historis, Strategis, dan Buffer Zone}

Bagi Rusia, Eropa Timur tentu merupakan kawasan penting dan strategis dalam sejarah bangsa Rusia. Sejak awal abad 19, paling tidak, dua peristiwa besar dalam sejarah Eropa yang menegaskan pentingnya kawasan Eropa Timur bagi negara Beruang Putih ini. Pertama, Perancis di era Napoleon Bonaparte pernah melakukan ekspansi wilayah dan petualangan militer dengan menyerang Moskow di tahun 1812. Dalam peristiwa tersebut, Rusia adalah korban ekspansi Perancis. Kedua, Jerman di era Adolf Hitler pernah menyerang Rusia dalam Perang 
Dunia II tahun 1941. Sekali lagi, Rusia menjadi korban petualangan militer Jerman. Dua peristiwa besar ini menunjukkan bahwa, dari sisi geopolitik dan keamanan, Rusia memang rentan dan pernah menjadi korban dari negara tetangga agresif yang terletak di sebelah Barat. Itulah alasan historis dan geopolitis bagi Rusia akan perlunya sphere of influence maupun buffer-zone di Eropa Timur untuk menahan kemungkinan berbagai serangan dari barat tersebut.

Selama Perang Dingin, Rusia di era Uni Soviet berhasil mendapatkan buffer-zone yang memadai untuk kepentingan strategis dari negara-negara yang tergabung dalam Uni Soviet (Ukraina, Belorussia, Estonia, Latvia, Lithuania, Moldova). Negara-negara ini adalah bagian dari Uni Soviet yang terletak di Eropa Timur. Buffer-zone bagi Rusia juga dari negara -negara komunis satelit di Eropa Timur (Polandia, Bulgaria, Romania, Cekoslovakia, dan Jerman Timur). Untuk mengimbangi kekuatan militer Barat, aliansi militer Pakta Warsawa didirikan dan berpusat di kota sebuah negara satelitnya di Eropa Timur, Warsawa, Polandia. Namun, peta geo-politik dan geostrategis berubah total sejak usainya Perang Dingin. Menjelang berakhinya perang dingin, negara-negara komunis di Eropa Timur rontok satu demi satu dan berubah mengarah ke demokrasi. Demikian pula, karena kebangkrutan ekonomi dan kegagalan lembaga politik tak bisa dielakkan, negara Uni Soviet akirnya juga bubar. Sebagai negara "pewaris" tunggal Uni Soviet, Rusia berupaya untuk mempertahankan sisa-sisa pengaruhnya di negara-negara mantan republik Soviet dengan membentuk sebuah Persemakmuran NegaraNegara Merdeka (CIS). Akan tetapi, Rusia pelan-pelan namun pasti semakin ditinggalkan oleh negara-negara mantan sekutunya.

Rusia pasca Soviet memang berada dalam posisi yang relatif lemah dari segi ekonomi. Hubungan Rusia dengan pihak Barat-Uni Eropa dan Amerika Serikatsempat membaik secara signifikan pasca Perang Dingin. Memang, Rusia juga sedang terjadi transisi politik dan ekonomi dan memerlukan support negara-negara BaratUni Eropa dan Amerika Serikat-untuk menata dan membangun kembali sistem ekonominya. Rusia pasca Soviet jelas sangat rentan dari sisi ekonominya. Namun di situlah letak permasalahannya: dalam situasi sulit dan rentan tersebut, pihak Barat-Uni Eropa dan Amerika Serikat-justru memanfaatkan kelemahan Rusia tersebut untuk mencukur gundul sisa-sisa pengaruh Rusia di Eropa Tengah dan Timur. Rangkaian peristiwa menunjukkan bahwa terjadi expansi pengaruh Barat di Eropa Tengah dan Timur secara sistematis yang merugikan Rusia yang sedang melemah itu. Beberapa peristiwa tersebut antara lain.

Pertama, adalah aksi Barat-Uni Eropa- dengan agresifnya dan secepatcepatnya menarik negara-negara mantan negara bagian Uni Soviet, seperti, Estonia, 
Latvia dan Lithuania ke pelukan Barat atau Uni Eropa. Demikian pula, negara-negara bekas satelit Uni Soviet di Eropa Timur seperti Polandia, Hungaria, Romania, Bulgaria Czeko, Slovakia, juga ditarik ke Uni Eropa. Bagi Barat (Uni Eropa), perluasan keanggotaan mencakup negara-negara mantan bagian Uni Soviet dan negara-negara mantan komunis di Eropa Timur adalah kisah sukses. Semakin banyak negara-negara Eropa Tengah dan Timur yang makin bergeser ke pelukan dan magnet kesuksesan Ekonomi Barat. Akan tetapi dilain pihak, bagi Rusia, perluasan Uni Eropa ke Eropa Timur itu adalah kisah tragis yang memilukan karena Rusia semakin ditinggalkan oleh bekas negara-negara sahabat -sahabatnya yg pernah berada dalam sphere of influence nya. Rusia semakin menjadi pihak yang kalah dalam pertarungan perebutan pengaruh ini.

Kedua, adalah peristiwa intervensi militer NATO di Kosovo untuk menggebuk tentara Serbia. Serbia adalah sekutu tradisional Rusia dan memiliki kesamaan sebagai bangsa Slav. Di bawah Milosevics, Serbia menggunakan sarana militer untuk mencegah Kosovo yang beretnis Albania memisahkan diri dari Serbia tahun 1999. Karena kekuatan militernya merupakan pewaris angkatan bersenjata Yugoslavia, penduduk Kosovo terancam jiwanya dan kemungkinan genocide bisa terjadi lagi, seperti Genocide di Srebrenica atas Muslim Bosnia. Waktu itu, tercatat, 300.000 warga Kosovo mengungsi di hutan dan terancam mati kedinginan di musim dingin. Alasan kemanusiaan ini menyebakan NATO melakukan intervensi penyelamatan dengan menyerang sahabat setia Rusia (Serbia). Kosovo akhirnya bisa merdeka atas dukungan NATO dan negara-negara barat. Yang menjadi problem bagi Rusia adalah bahwa Serbia merupakan sekutu tradisional Rusia. Dengan digebuknya Serbia menyebabkan sentimen anti-barat di Rusia meningkat. Waktu itu, jajak pendapat di Rusia menyebutkan bahwa kebanyakan warga Rusia sinis melihat intervensi NATO dan menganggap alasan strategis NATO di kawasan Balkan, bukan alasan kemanusiaan. Perasaan ketidakpercayaan dan sikap antiBarat di kalangan warga Rusia semakin meningkat.

Ketiga, Barat juga terus berupaya sistematis menggunduli Rusia dalam bidang militer. Barat dengan rencana untuk menempatkan sistem pertahanan canggih rudal -anti rudal di Eropa Timur. Dalih Amerika Serikat yang dsampaikan adalah untuk mencegah rudal yang mungkin diluncurkan dari Iran, bukan untuk diarahkan kepada Moskow. Namun, bagi Rusia, rencana tersebut sangat mengkawatirkan karena akan dipandang melemahkan kemampan militer Rusia dan mengancam perjanjian yang menjamin perimbangan strategis global. Rencana penempatan sistem pertahanan anti-rudal tersebut membuat Rusia sangat khawatir karena posisi keamanannnya akan semakin 
rentan. Artinya, Eropa bisa kebal terhadap kemungkinan serangan rudal yang memasuki wilayah udaranya, sedangkan Rusia tidak. Rencana penempatan sistem pertahanan rudal anti-rudal NATO bisa dipahami telah memicu kemarahan Rusia karena posisi keamanannya semakin terusik. Bahkan jenderal Nikolai Makarov, komandan paling senior Rusia waktu itu pernah secara emosional memperingatkan pihak Barat-khususnya Amerika serikatbahwa, bila rencana tersebut tetap dilanjutkan maka Rusia tak segan-segan akan menggunakan kekuatan militer untuk menyerang instalasi militer Barat di Polandia dan Romania. Intinya, ekspansi pengaruh Barat ke negara-negara Eropa Timur era Pasca Perang Dingin yang tanpa perasaan itulah sebenarnya peyebab ketegangan antara Barat dengan Rusia.

\section{Kalkulasi Strategis, Psikologis, dan Balance Of Power}

Babak baru pecahnya ketegangan antara Barat dengan Rusia terjadi ketika secara mengagetkan Rusia melakukan tindakan aneksasi wilayah Ukraina, yakni, Semenanjung Krimea. Peristiwa tersebut terjadi setelah pecahnya krisis politik dalam negeri Ukraina pasca penolakan Presiden Viktor Yanukovych untuk menandatangani perjanjian perdagangan dengan pihak Uni Eropa. Kebijakan tersebut memicu kemarahan rakyat Ukraina yang proBarat sehingga mereka menggelar demonstrasi rakyat besar-besaran di kota Kiev. Puncak ketegangan terjadi ketika insiden berdarah pecah di Kiev yang menewaskan 100 demonstran. Presiden Yanukovych akhirnya tumbang dan melarikan diri ke Rusia.

Rusia tentu berkepentingan untuk mengikuti dengan seksama perkembangan drama krisis politk di Ukraina tersebut. Bagi Rusia, kejatuhan tragis Presiden Yanukovych yang pro-Rusia tentunya akan menyebabkan Rusia segera akan kehilangan satu lagi negara sahabat dekatnya, Ukraina. Bisa dipastikan, Ukraina yang dipimpin presiden baru yang condong ke Barat akan segera mengikuti jejak negara-negara mantan komunis lainya yang melakukan re-orientasi politik luar negerinya ke Barat pula dan meninggalkan Rusia. Bak teori domino yang popular di masa Perang Dingin, teori tersebut juga berlaku: ketika satu negara sahabat Rusia jatuh ke tangan Barat maka negara-negara sahabat Rusia yang lain mengikutinya dan bergiliran jatuh ke Barat, Uni Eropa. Lagi-lagi, Rusia menjadi pihak kalah.

Pertanyaan kemudian, setelah mengupas latar belakang di atas, mengapa Rusia melakukan aksi aneksasi terhadap semenanjung Krimea? Tidak perlu diperdebatkan lagi bahwa tindakan Rusia adalah jelas tindakan illegal menurut norma hukum internasional. Bahkan kecaman dunia internasional kepada Rusia sangat keras. Duta besar Amerika Serikat di Perserikatan Bangsa-Bangsa (PBB) menyebut tindakan aneksasi Rusia tersebut sebagai "maling." Untuk melegitimasikan tindakan sepihaknya, Rusiapun segera mengadakan 
referendum di wilayah yang dianeksasi untuk menegaskan bahwa tindakan Rusia adalah Sah. Sekali lagi, referendum sepihak tidaklah menjadikan tindakan aneksasi tersebut menjadi sah secara hukum internasional. Barat dan masyarakat internasional menolak hasil referendum. Namun permasalahannya bukan masalah hukum, tetapi aneksasi tersebut tentu lebih banyak bernuansa politis, psikologis, maupun strategis.

Pertama, adalah faktor kepentingan strategis Russia. Rusia sudah lama memiliki pangkalan militer angkatan laut di Sevastopol di Krimea. Pangkalan angkatan laut strategis tersebut disewa Rusia dari Ukraina dan telah diperpanjang sampai dengan 2042. Perpanjangan kontrak sewa pangkalan angkatan laut dengan Kiev bisa terjadi hanya karena diplomasi yang cukup alot. Pangkalan ini letaknya sangat strategis bagi Rusia karena di pangkalan Laut Hitam inilah kapal-kapal perang Rusia tetap leluasa beroperasi di musim dingin karena lautnya yg tidak beku. Kontrak sewa pangkalan Rusia di Ukraina tersebut mungkin tidak menjadi masalah selama pemerintah di Kiev adalah pro-Moskow. Namun, dengan kejatuhan Presiden Janukovych yang proMoskow, maka masa depan pangkalan angkatan laut strategis Rusia tersebut bisa menjadi tidak menentu. Sebagai titik strategis kekuatan militer di laut Hitam, Rusia jelas tidak akan merelakan kemungkinan penutupan pangkalan angkatan laut ini di masa depan. Bagi Rusia, aneksasi adalah pilihan tindakan rasional bagi Rusia.

Kedua, adalah faktor psikologis. Setelah bubarnya Perang Dingin, Rusia di bawah Boris Yeltsin sebenarnya melakukan reorientasi Politik Luar Negerinya pelan-pelan mendekat ke Barat. Akan tetapi Moskow kemudian kecewa karena pihak Barat ternyata masih menyimpan rasa ketidakpercayaan kepada Rusia. Bertahun-tahun Rusia berupaya namun tidak berhasil mencapai apa yang paling dia inginkan: keanggotaan yang sederajad terhadap Barat serta kemakmuran ekonomi. Benar bahwa Russia sudah menjadi anggota eksklusif kelompok G8, namun tak pernah menikmati status sama dengan tujuh negara anggota yang lain: masih saja Rusia dianggap sebagai "yang lain." Secara ekonomi, shock therapy yang diusulkan Barat dan diimplementasikan secara ikhlas oleh Boris Yeltsin justru tidak membawa kemajuan ekonomi yang diharapkan. Namun, ekonomi Rusia justru memburuk menyebabkan kehidupan rata-rata masyarakat Rusia dari sebelumnya. Rusia memang pernah berupaya mendekat ke Barat, namun berakhir dengan suatu kekecewaan, penghinaan dan bencana. (Zongyou, 2014). Dengan melakukan aksi aneksasi Krimea, Rusia ingin membuktikan kepada Barat bahwa Rusia adalah negara besar yang tak bisa diremehkan dan dipermainkan.

Ketiga, Presiden Vladimir Putin berambisi untuk membangunkan kembali kejayaan Rusia era Soviet. Ketika ekonomi Rusia semakin baik, Barat justru menghadapi berbagai 
permasalahan. Tahun 2008 krisis ekonomi menggoyang ekonomi Amerika dan kemudian disusul krisis hutang di beberapa negara anggota Uni Eropa. Namun, sebaliknya, Rusia justru mulai bangkit sebagai kekuatan ekonomi. Sebenarnya saat ini Inggris, Perancis, atau bahkan Jermanlah yang sibuk untuk meminta para pengusaha minyak Rusia untuk membeli dan melakukan lebih banyak investasi.

Perlu ditambahkan pula bahwa the balance of power antara Rusia dan Barat sedang mengalami pergeseran. Perang kecil di Georgia musim panas 2008 hanya memperkuat kecenderungan ini dan response dari Barat memberikan kesan mendalam kepada Rusia: Eropa dan Amerika Serikat saat ini sedang memudar dan makin melemah untuk memimpin (Zongyou, 2014). Sebaliknya, Rusia yang sedang bangkit, tentu tak akan membiarkan Ukraina-sebuah negara Republik mantan Soviet yang sangat strategis - jatuh sepenuhnya ke pelukan pihak Barat. Dengan melakukan aneksasi Semenanjung Krimea, Presiden Putin tidak hanya mengamankan pangkalan angkatan lautnya dan jalur strategisnya di laut hitam, tetapi juga mengirimkan sinyal kuat ke Ukraina dan Barat, "Ignore Russia's legitimate strategic concerns at your own peril" (Zongyou, 2014). Presiden Putin dalam pidatonya mengatakan bahwa Rusia sebenarnya tidak memiliki ambisi untuk menjadi hegemon global ataupun regional, namun Rusia hanya ingin menjadi salah satu negara yang menentukan politik internasional.

\section{Respon Barat: Dilema Menghukum Negara "Great Power"}

Tindakan Rusia melakukan aneksasi Krimea maupun intervensinya di Ukraina Timur jelas melanggar norma hukum internasional dan tatanan internasional. Namun permasalahannya sekali lagi bukan masalah hukum tetapi masalah politik dan keamanan nasional Rusia. Rusia adalah sebuah great power atau bahkan masih superpower militer-dalam arti kemampuan dan kapabilitas militernya masih termasuk yang terkuat di dunia. Disamping Rusia merupakan negara nuklir terbesar, Rusia bukanlah negara sembarangan karena posisi politik sangat kuat karena merupakan salah satu anggota tetap Dewan Keamanan Perserikatan Bangsa Bangsa (PBB). Bagi Amerika Serikat dan Uni Eropa, respon seperti apa yang pas untuk mengukum Rusia itulah yang sangat dilematis. Upaya yang sudah dilakukan Barat adalah melakukan isolasi diplomatik dan sanksi ekonomi terhadap Rusia walaupun keduanya bukan tanpa masalah.

Sejak awal, Amerika Serikat dan Uni Eropa melakukan penggalangan diplomasi yang intensif dan sepakat mengutuk Rusia atas tindakannya tersebut. Barat memperingatkan Rusia bahwa Barat siap untuk meningkatkan sanksi ekonomi lebih berat jika Putin melakukan intervensi lebih luas ke wilayah 
Ukraina Timur. Dalam implementasinya, para pemimpin kelompok negara Maju (G8) sepakat untuk memecat Rusia sebagai anggota sampai Presiden Putin mau merubah sikapnya. G7 selanjutnya mengadakan pertemuan musim panas di Brussel, secara simbolis bertemu di Markas Uni Eropa dan NATO, dua organisasi yang sedang memberkuat hubungan dengan Ukraina.

Di bidang diplomatik. Dalam Majelis Keamanan Perserikatan Bangsa Bangsa, Presiden Amerika Serikat Barack Obama berupaya melobi China agar mendukung posisi Barat. China akhirnya abstain ketika diadakan voting tentang illegalitas tindakan aneksasi Krimea oleh Rusia. Tiga belas negara Anggota Dewan Keamanan setuju, dan hanya Rusia yang mem-veto. Artinya, Moskow memang beul-betul terisolasi secara diplomatik karena tindakannya. Sebuah pukulan diplomatik berat atas Rusia di Dewan Keamanan PBB.

Di bidang ekonomi. Disamping itu Barat juga menerapkan sanksi ekonomi terbatas dengan target orang-orang kunci dalam pemerintahan Rusia, para eksekutif senior, CEO yang mengendalikan perusahaaan manufaktur besar di Rusia dan dekat dengan pemerintah. Tindakannya Barat termasuk diantaranya adalah pembekuan asset mereka. Kelompok G7 juga merencanakan sanksi terhadap sektor-sektor ekonomi strategis Rusia jika Rusia terus melanjutkan intervensi atau mencaplokan wilayah selatan dan timur Ukraina, wilayah di mana penduduknya adalah etnis Rusia. Sektor strategis yang bisa menjadi target sanksi ekonomi antara lain sektor industri energi, sektor perbankan, dan sektor pertahanan. Namun langkah Amerika juga tidak mudah. Presiden Obama berupaya untuk mendapatkan dukungan dari para pemimpin Eropa yang mungkin justru kuwatir langkahlangkah tersebut menjadi bumerang bagi ekonomi Eropa sendiri. Perlu dicatatat bahwa Rusia adalah salah satu dari mitra dagang terbesar Uni Eropa dan pemasok sumber enegi Eropa secara signifikan. Rusia bukan negara kecil. Artinya, sanksi terhadap Rusia juga merugikan kepentingan ekonomi Uni Eropa juga.

Di bidang militer. Apapun yang akan dilakukan Rusia terhadap Ukraina-bahkan seandainya invasi militer-kecil kemungkinan NATO akan ambil resiko terlibat konflik langsung dengan Rusia. Konflik terbuka antara NATO dan Rusia terlalu mahal resiko yang akan ditanggung oleh NATO, dan yang sangat mengkhawtirkan adalah bahwa Rusia merupakan pemilik senjata nuklir besar di dunia. NATO tidak mau mengambil resiko konfrontasi langsung dengan Rusia bila saja negeri ini diinvasi oleh Rusia. Disamping kekawatiran akan terjadi konfrontasi langsung, tetapi juga karena organisasi di NATO sendiri Ukraina bukanlah anggota. Namun, NATO masih bisa berperan untuk mencegah rencana Rusia dengan mengirim sinyal bantuan militer supaya terjadi deterrence effect dengan member bantuan militer ke negara tetangga 
Rusia seperti Estonia.

\section{Catatan Akhir}

Berbeda dengan optimisme pendekatan liberal tentang tatanan dunia dewasa ini, peristiwa yang mencengangkan bagai petir di siang bolong terjadi di tahun 2015, yakni: tindakan anaksasi Rusia atas Krimea dan diikuti dengan intervensinya mendukung kelompok pemberontak pro-Rusia di Ukraina Timur. Tulisan ini telah membahas dinamika hubungan antara Rusia dan BaratUni Eropa dan Amerika Serikat-yang memburuk terkait dengan dengan Ukraina. Tindakan Rusia yang melakukan aneksasinya terhadap semenanjung Krimea dan intervensinya mendukung pihak pemberontak pro-Rusia di Ukraina Timur di satu sisi dan dilemma yang dihadapi Barat dalam meresponse tindakan Rusia tersebut di sisi yang lain menjadi fokus pembahasan. Inti argumennya adalah bahwa tindakan Rusia merupakan hal yang bisa dipahami sebagai puncak reaksi terhadap ekspansi pengaruh Barat secara masif ke Eropa Timur pasca Perang Dingin. Ukraina hanyalah salah satu sisa-sisa dan benteng akhir mitra Rusia di Eropa Timur. Kejatuhan tragis presiden Viktor Janukovych yang pro-Rusia di negara tersebut hanyalah menjadi faktor pemicu bagi tindakan Rusia. Sejauh mana efektifitas reaksi Barat yang berupa, sanksi ekonomi dan diplomatik atas Rusia belum bisa dipastikan. Namun bagi Barat, aneksasi Rusia atas Semenanjung Krimea dan intervensi Rusia dengan mendukung pihak pemberontak pro-Rusia di Ukraina Timur sangatlah mengkhawatirkan dan memicu ketegangan yang serius antara Barat dan Rusia. Bagi Barat, upaya mengendalikan tindakan "illegal" Rusia cukup dilematis mengingat Rusia adalah negara great power. Selamat datang kembali Perang Dingin! 
Ali Muhammad

\section{Daftar Pustaka}

Bellah, Robert. 1957. Tokugawa Religion. New York: The Free Press.

Bolitho, Harold. 1974. Treasures Among Men: The Fudai Daimyo in Tokugawa Japan. New Haven: Yale University Press

Budiman, Kazuko. 2006. Sastra Agama Endo Shusaku: Dilema Memahami Tuhan. Depok: Universitas Indonesia.

- - - - - 2004. Imaji Tuhan dalam Novel Chimmoku Karya Endo Shusaku. Depok: Universitas Indonesia.

Chen Ka. 2007. Endo Shuusaku 'Chinmoku' no Kenkyuu-Nihon-teki Seishin Fuushi no Shouchou: Inoue Gomori ni tsuite - Nagasaki: Nagasaki University's Academic

Endo, Shusaku. 1972. Chimmoku (Silence). Tokyo: The Kawata Press.

Gorai, Shigeru. 2002. Nihonjin to Gokuraku. Kyoto: Jinbunshoin.

Perry, Anderson. 1976. The Antinomies of Antonio Gramsci. London: New Left Review. 